African Crop Science Journal by African Crop Science Society is licensed under a Creative Commons Attribution 3.0 Uganda License. Based on a work at www.ajol.info/ and www.bioline.org.br/cs DOI: https://dx.doi.org/10.4314/acsj.v26i4.8

\title{
LIMITING NUTRIENTS FOR BEAN PRODUCTION ON CONTRASTING SOIL TYPES OF LAKE VICTORIA CRESCENT OF UGANDA
}

\author{
P. KYOMUHENDO, M.M. TENYWA, O. SEMALULU' ${ }^{1}$, A.W. LENSSEN ${ }^{2}$, R.S. YOST ${ }^{3}$, R.E. MAZUR ${ }^{2}$, \\ S. KYEBOGOLA and L.H. GOETTSCH ${ }^{2}$ \\ College of Agricultural and Environ. Sciences, Makerere University, P. O. Box 7062, Kampala, Uganda \\ ${ }^{1}$ National Agricultural Research Laboratories (NARL) Kawanda, P. O. Box7065, Kampala, Uganda \\ ${ }^{2}$ Iowa State University, Ames, Iowa 50011-1010, USA \\ ${ }^{3}$ Tropical Plant and Soil Sciences, University of Hawai'i at Manoa Honolulu, Hawai ‘ $i$ \\ Corresponding author: prossykyomuhendo@gmail.com
}

(Received 15 January, 2018; accepted 3 October, 2018)

\begin{abstract}
Common bean (Phaseolus vulgaris L.) is one of the most important grain legumes in East Africa, but its yield has remained below the genetic potential. Declining soil fertility is among the primary constraints to bean production in most East African bean producing regions. Often existing recommendations are generic and inept to guide farm level decision making on nutrient replenishment. A greenhouse nutrient omission study was conducted to determine the limiting nutrients in three soils of Masaka District, commonly cropped to beans: "Liddugavu" a Phaeozem, "Limyufumyufu" a Cambisol and "Luyinjayinga" an Umbrisol soil. Nine treatments; (i) complete nutrient treatment, (ii) $\mathrm{N}$ omitted, (iii) $\mathrm{P}$ omitted, (iv) K omitted, (v) Mg omitted, (vi) S omitted, (vii) Ca omitted, (viii) Micronutrients omitted and (ix) control without nutrients. Each treatment was randomly assigned to the three soils and replicated three times using a completely randomised design. Nitrogen, phosphorus and potassium were limiting nutrients for bean production in Umbrisol (Luyinjayinja) while in Cambisol ('Limyufumyufu), common bean production was most limited by soil acidity. The performance varied with soil types, with beans grown on the Phaeozem registering greater leaf number and growth, confirming both scientist's and local farmer's knowledge that this soil has greater potential than the other two soils.
\end{abstract}

Key Words: Cambisol, Phaeozem, Phaseolus vulgaris, Umbrisol

\section{RÉSUMÉ}

Le haricot commun (Phaseolus vulgaris L.) est un des légumes à grains les plus importants en Afrique de l'Est, mais son rendement reste toujours en dessous de son potentiel génétique. La baisse de la fertilité du sol est parmi les contraintes primaires à la production du haricot dans la plupart des régions productrices de l'Afrique de l'Est. Le plus souvent, les recommandations sont génériques et inadéquates pour guider la prise de décision au niveau champ sur le réapprovisionnement en nutriment. Une étude sous serre sur l'omission de nutriment a été conduite pour déterminer les nutriments limitants dans les trois sols du district de Masaka, communément utilisés pour produire du haricot : "Liddugavu" un sol du Phaeozem, "Limyufumyufu" un sol du Cambisol et "Luyinjayinga" un sol du Umbrisol. Neuf traitements, (i) traitement complet de nutriments, (ii) $\mathrm{N}$ omis, (iii) P omis, (iv) K omis, (v) $\mathrm{Mg}$ omis, (iv) $\mathrm{S}$ omis, (vii) Ca omis, (viii) micronutriments omis et (ix) control sans nutriments. Chacun des traitements a été aléatoirement distribué aux trois types de sols et répliqué trois fois dans un dispositif complètement aléatoire. Azote, phosphore, et potassium ont été les nutriments limitants pour la production du haricot dans 
Umbrisol (Luyinjayinja) tandis que dans Cambisol ('Limyufumyufu), la production du haricoct commun a été limitée par l'acidité du sol. Les performances varient en fonction des types de sols, avec le haricot produit sur le Phaeozem comptant plus de feuilles et de croissance, confirmant à la fois les connaissances des scientifiques et des populations locales qui stipulent que le sol a un potentiel plus élevé que les deux autres sols.

Mots Clés: Cambisol, Phaeozem, Phaseolus vulgaris, Umbrisol

\section{INTRODUCTION}

Common bean (Phaseolus vulgaris L.) is the most widely grown grain legume, and second only to maize as a food crop and a major source of food security in East Africa (Mauyo et al., 2007). Bean production in Uganda primarily occurs in the central, eastern and western regions (Sibiko et al., 2013). Farmers in the Lake Victoria crescent of Uganda mainly grow common beans on three soil types locally classified as: Liddugavu (Phaoezem), Limyufumyufu (Cambisol) and Luyinjayinja (Umbrisol) (Tenywa et al., 2014). However, yields are still below the genetic potential (Anon., 2013).

In order to increase yield, some farmers have attempted to use inorganic fertilisers $(1.3 \%)$, manure $(8.7 \%)$ (UBOS, 2006) and inorganic foliar sprays (Kabuga et al., 2015), but the response has not been consistent (Sanginga and Woomer, 2009) especially on Umbrisol and Cambisol soils.

In East Africa, limited $\mathrm{N}$ and $\mathrm{P}$ availability (Beebe et al., 2010) is the major production constraint to bean production. This study was conducted to determine the most limiting nutrients in Phaeozem, Cambisol, and Umbrisol soils commonly used for bean production in Uganda.

\section{MATERIALS AND METHODS}

A two cycle potted experiment was conducted with the first cycle at the Makerere University Agricultural Research Institute Kabanyolo (MUARIK); while the second one at the National Agricultural Research Laboratories (NARL), Kawanda.
Study soil collection and preparation. The study soil was collected from three communities (Mukungwe, Kabonera and Lwankoni) in Masaka district located in central Uganda, at $31.7361^{\circ} \mathrm{E}$ latitude and $0.34111^{\circ} \mathrm{S}$ longitude on the three most agriculturally important soil types in farmer's fields. These soils were selected for study based on a series of farmer meetings from three communities, which indicated that these were the three most important, farmer-recognised soil series for common bean production. Soil samples were obtained in a zig-zag pattern at ten locations within each field, from a depth of $0-15 \mathrm{~cm}$. A bulk sample of about $170 \mathrm{~kg}$ was obtained from an area of approximately $50 \mathrm{~m} \times 100 \mathrm{~m}$ for each soil type. A total of about $500 \mathrm{~kg}$ of soil was taken for greenhouse experiment and laboratory analyses. Composite samples obtained from the bulk samples were air dried in a dust free area, and the portion to be used for nutrient omission study was disaggregated and crushed with a mortar and pestle to pass a 5-mm sieve (Johnston and Askin, 2005). The samples were subsequently used for physicochemical analyses, after crushing them to pass a 2-mm sieve.

Experimental design. The pot experiment was laid out in a completely randomised design (CRD), with nine treatments (Table 1). Each nutrient treatment was randomly assigned to portions of each of the three soils. Table 1 shows the treatments used in the experiment, while Table 2 shows the nutrient ingredients and application rates.

The experiment was conducted in plastic pots with $2.5 \mathrm{~kg}$ of soil in each pot. Common bean variety BAT 477 was selected as the test 
TABLE 1. Treatments and nutrients applied in the omission study conducted at Makerere University Agricultural Research Institute Kabanyolo and National Agricultural Research Laboratories in Uganda

\begin{tabular}{ll}
\hline Nutrient treatment & Nutrients added \\
\hline Control & No nutrients added \\
Complete nutrient treatment & $\mathrm{N}, \mathrm{P}, \mathrm{K}, \mathrm{Mg}, \mathrm{Ca}, \mathrm{S}$, Micronutrients \\
N omitted & $\mathrm{P}, \mathrm{K}, \mathrm{Mg}, \mathrm{Ca}, \mathrm{S}$, Micronutrients \\
P omitted & $\mathrm{N}, \mathrm{K}, \mathrm{Mg}, \mathrm{Ca}, \mathrm{S}$, Micronutrients \\
K omitted & $\mathrm{N}, \mathrm{P}, \mathrm{Mg}, \mathrm{Ca}, \mathrm{S}$, Micronutrients \\
Mg omitted & $\mathrm{N}, \mathrm{P}, \mathrm{K}, \mathrm{Ca}, \mathrm{S}$, Micronutrients \\
S omitted & $\mathrm{N}, \mathrm{P}, \mathrm{K}, \mathrm{Mg}, \mathrm{Ca}$, Micronutrients \\
Ca omitted & $\mathrm{N}, \mathrm{P}, \mathrm{K}, \mathrm{Mg}, \mathrm{S}$, Micronutrients \\
Micro nutrients omitted & $\mathrm{N}, \mathrm{P}, \mathrm{K}, \mathrm{Mg}, \mathrm{Ca}, \mathrm{S}$ \\
\hline
\end{tabular}

TABLE 2. Nutrient stock solutions and application rates for the nutrient omission study conducted at Makerere University Agricultural Research Institute Kabanyolo and National Agricultural Research Laboratories in Uganda

\begin{tabular}{lcl}
\hline Element & Nutrient application rate $\left(\mathrm{kg} \mathrm{ha}^{-1}\right)$ & $\mathrm{Compound}$ \\
\hline $\mathrm{N}$ & 100 & $\mathrm{Urea}$ \\
$\mathrm{P}$ & 100 & $\mathrm{NaH}_{2} \mathrm{PO}_{4} \cdot 2 \mathrm{H}_{2} \mathrm{O}$ \\
$\mathrm{K}$ & 100 & $\mathrm{KCl}$ \\
$\mathrm{Mg}$ & 35 & $\mathrm{MgCl}_{2} \cdot 6 \mathrm{H}_{2} \mathrm{O}$ \\
$\mathrm{Ca}$ & 30 & $\mathrm{CaCl}_{2}$ \\
$\mathrm{~S}$ & 25 & $\mathrm{Na}_{2} \mathrm{SO}_{4}$ \\
$\mathrm{Fe}$ & 5 & $\mathrm{FeNaEDTA}^{\mathrm{a}}$ \\
$\mathrm{B}$ & 2 & $\mathrm{H}_{3} \mathrm{BO}_{3}$ \\
$\mathrm{Mn}$ & 5 & $\mathrm{MnCl}_{2} \cdot 4 \mathrm{H}_{2} \mathrm{O}$ \\
$\mathrm{Zn}$ & 4 & $\mathrm{ZnCl}_{2}$ \\
$\mathrm{Mo}$ & 3 & {$\left[\mathrm{NH}_{4}\right]_{6} \mathrm{Mo}_{7} \mathrm{O}_{24} \cdot 4 \mathrm{H}_{2} \mathrm{O}$} \\
$\mathrm{Cu}$ & 0.4 & $\mathrm{CuCl}_{2} \cdot 2 \mathrm{H}_{2} \mathrm{O}$ \\
$\mathrm{Co}$ & 0.1 & $\mathrm{CoCl}_{2} \cdot 6 \mathrm{H}_{2} \mathrm{O}$ \\
$\mathrm{Ni}$ & 0.1 & $\mathrm{NiCl}_{2} \cdot 6 \mathrm{H}_{2} \mathrm{O}$ \\
\hline
\end{tabular}

crop because of its acid tolerance characteristics and high nitrogen fixation ability (Kipe-Nolt and Giller, 1993) Four seeds were sown in each pot at planting, and later thinned to two plants per pot, five days after emergence (DAE).

The Hoagland (1950) nutrient solution was used for the micronutrient and the concentrations of the macronutrients were chosen based on concentration ranges proposed by Hewitt (1952).

Data collection. From eleven days after emergence (DAE), regular observations were made to detect occurence of visual nutrient deficiency symptoms on foliar parts of plants (Foli, 2012). The number of leaves per plant and the above ground dry matter production 
measurements were taken to monitor growth of beans. To accurately record the data for above ground dry matter, the experiment was closely monitored and fallen leaves captured and kept in labeled polythene bags. These were added to the dry matter after plant harvest and oven dried together. The two surviving plants were harvested at six weeks (42 days after planting) by cutting at the base of the plant. Plant fresh weight was recorded, then samples were oven dried at $70{ }^{\circ} \mathrm{C}$ for 72 hours, and weighed again for dry weight. Dry samples were ground and analysed for macro- and micronutrient concentrations.

Laboratory analyses. Total soil organic carbon was analysed using the dry combustion method; while available $P$ was determined using Olsen method described in Okalebo et al. (2002). Exchangeable $\mathrm{K}^{+}$and $\mathrm{Na}^{+}$were determined using a flamephotometer, while $\mathrm{Ca}^{2+}$ and $\mathrm{Mg}^{2+}$ were determined using an atomic absorption spectrometer. Soil $\mathrm{pH}$ was measured in a $1: 2.5$ soil to water ratio using a pH electrode. The Kjeldahl method was used to determine total N (Bremner, 1965). Micronutrients were extracted in Mehlich 3 extractant solution (Mehlich, 1984). Micronutrients such as $\mathrm{Cu}, \mathrm{Mn}$ and $\mathrm{Zn}$ were measured by atomic absorption, while Boron was measured by colorimetric (Berger and Truog, 1939). Soil texture was determined using hydrometer method (Bouyoucos, 1936).

Statistical analysis. The above ground dry matter and number of leaves per plant data were subjected to analysis of variance using GenStat edition 12. Mean separations were done using Tukey Multiple Comparison test (Tukey, 1949).

\section{RESULTS}

Initial physico-chemical properties. All the study soils had a textural class of sandy clay loam (Table 3). Bulk density was 1.4, 1.3 and $1.4 \mathrm{~g} \mathrm{~cm}^{-3}$ for Phaeozem, Cambisol, and Umbrisol, respectively. The concentrations of

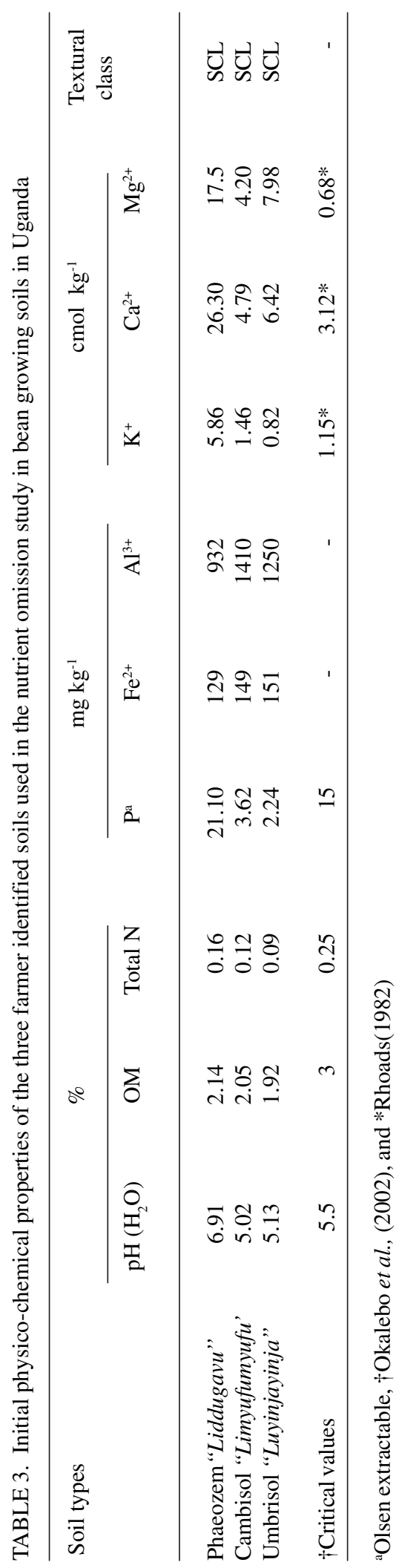


available phosphorus and nitrogen were below the critical levels in Cambisol and Umbrisol soils (Table 3). Olsen Extractable P and soil $\mathrm{pH}$ were above the critical levels in Phaeozem (Okalebo et al., 2002).

Soil type and above ground dry matter production. Plants grown in Phaeozem yielded significantly $(\mathrm{P}<0.05)$ higher above ground dry matter than did plants grown in other soil types (Fig. 1). For instance, plants grown in the Phaeozem soil yielded $27.7 \%$ and $33.6 \%$ greater $(\mathrm{P}<0.05)$ above ground dry matter than those grown in Umbrisol and Cambisol, respectively. On the other hand, bean dry matter obtained from Umbrisol was closely similar to that of Cambisol (Fig. 1).

Effect of nutrient omission on dry matter production in Phaoezem. Plants grown in cases where $\mathrm{N}$ or $\mathrm{Ca}$ were omitted accumulated 16.3 and $23 \%$ respectively, lower above ground dry mater than those grown in the complete treatment, but they were not significantly different $(\mathrm{P}>0.05)$ from plants grown the complete treatment (Fig. 2). The least above ground dry matter was realised from plants grown in the control treatment, which was also significantly $(\mathrm{P}<0.05)$ different from the complete treatment (Fig. 2).

The above ground dry matter in the complete treatment was similar to that of the nutrient omission treatments for $\mathrm{P}, \mathrm{N}$ and $\mathrm{Ca}$, while the values obtained from $\mathrm{S}, \mathrm{K}, \mathrm{Mg}$ and micronutrients omitted treatments were significantly higher than those of the complete treatment. The highest above ground dry matter was with micronutrients omission which was significantly $(\mathrm{P}<0.05)$ different from the $-\mathrm{P}$, complete, $-\mathrm{N},-\mathrm{Ca}$ and the control, but not significantly $(\mathrm{P}>0.05)$ different from the $-\mathrm{Mg},-\mathrm{S}$, and $-\mathrm{K}$ (Fig. 2).

Nutrient omission and dry matter production in Umbrisol. Plants grown in the control and treatments where N, P and $\mathrm{K}$ were omitted accumulated significantly $(\mathrm{P}<0.05)$ lower above ground dry mater than those grown in the complete treatment (Fig. 3). The least above ground dry matter was realised

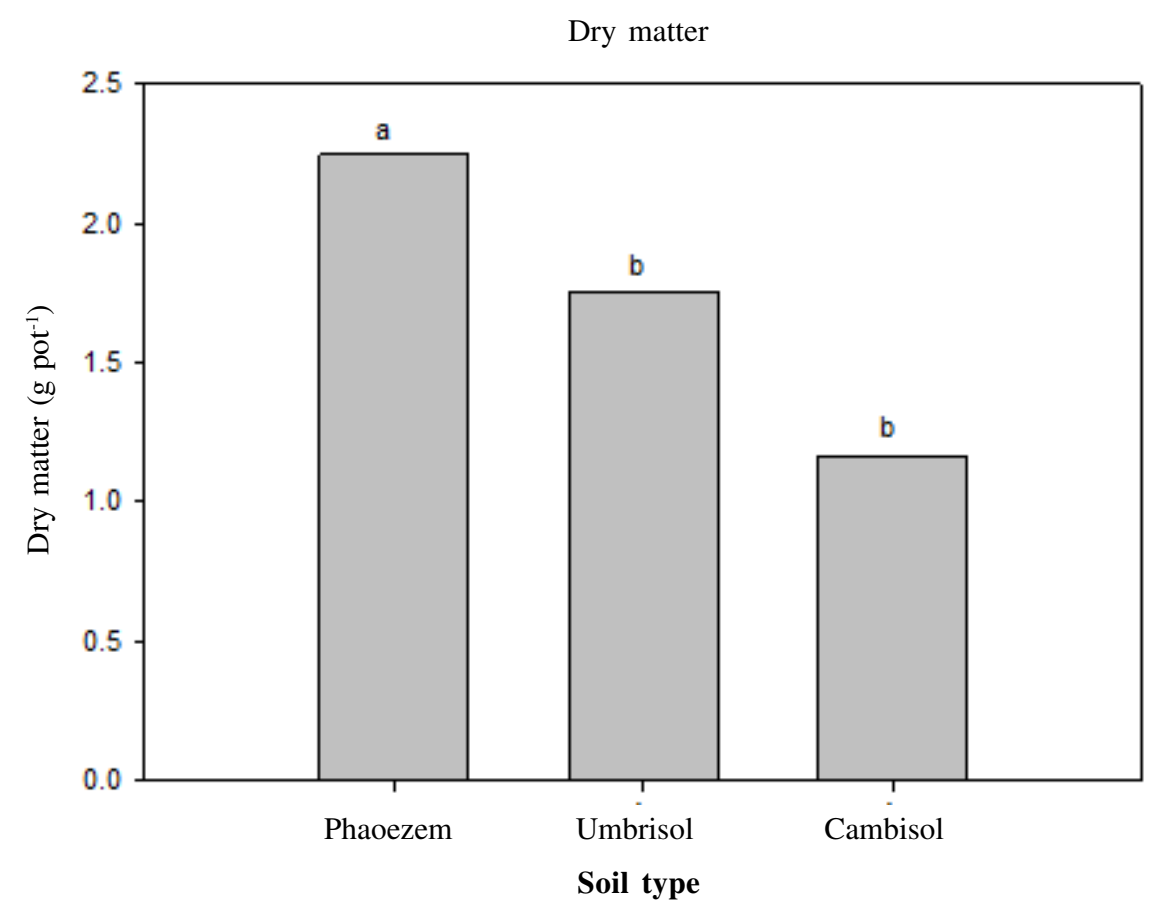

Figure 1. Above ground dry matter production under three soil types in Masaka District, Uganda. 


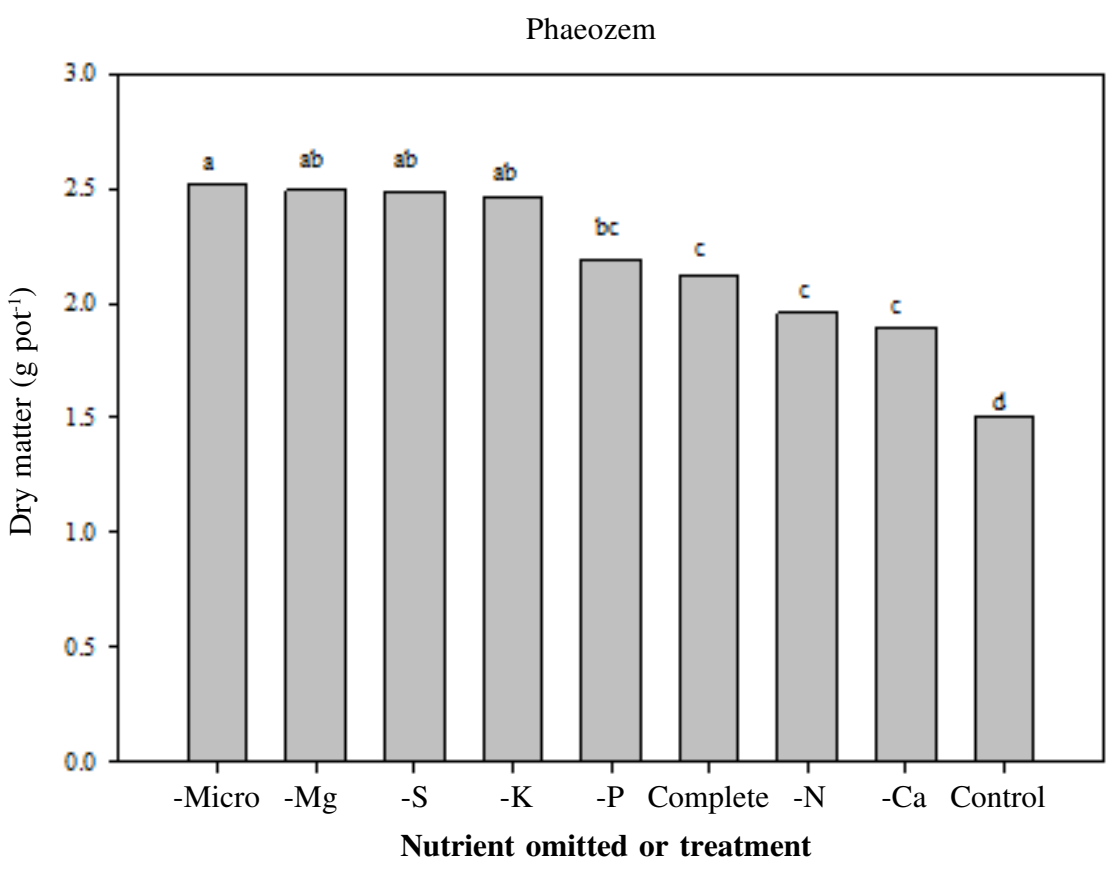

Figure 2. Above ground dry matter production in a Phaoezem in a nutrient omission study.

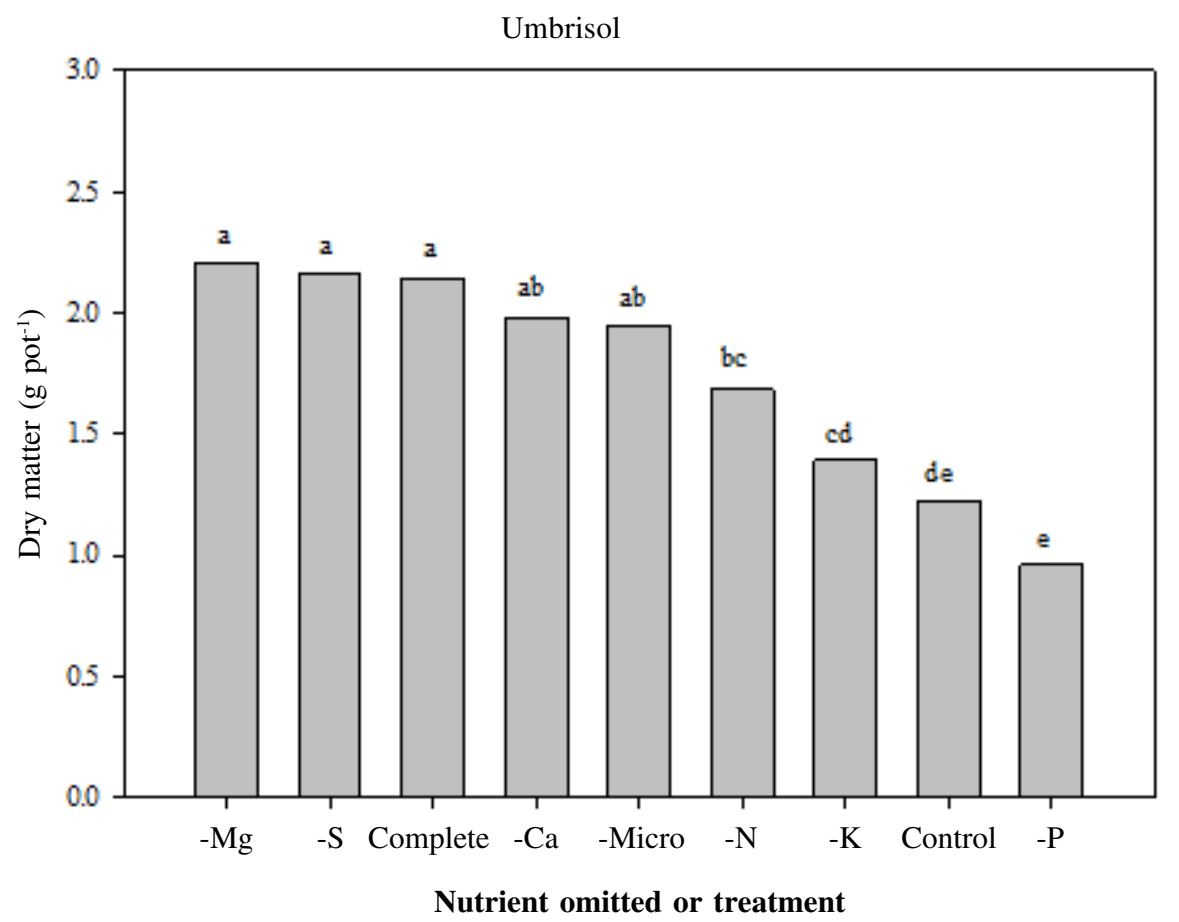

Figure 3. Bean above ground dry matter production in an Umbrisol in a nutrient omission study. 
from the $\mathrm{P}$ omitted treatment, which was significantly $(P<0.05)$ lower than what was realised from the treatments where nitrogen and potassium were omitted (Fig. 3).

The above ground dry matter in the complete treatment was similar to that of the nutrient omissions for $\mathrm{Ca}, \mathrm{Mg}, \mathrm{S}$ and micronutrients. The highest above ground dry matter was in $\mathrm{Mg}$ omitted treatment; though, this was not significantly $(\mathrm{P}>0.05)$ different from the complete, $-\mathrm{Ca},-\mathrm{S}$, and -micronutirent treatments (Fig. 3).

Effect of soil type on number of leaves per plant. Plants grown in Phaeozem had significantly $(\mathrm{P}<0.05)$ more leaves than plants grown in Cambisol and Umbrisol (Fig. 4). However, the number of leaves from beans grown in Umbrisol was not significantly different from that of the Cambisol.

Nutrient omission and number of leaves per pot in Cambisol. Plants grown in the control (without nutrients) in the Cambisol had the fewest number of leaves per plant, and they were significantly $(\mathrm{P}<0.05)$ different from those in the complete nutrient treatment. Incidentally, the number of leaves in phosphorus and calcium omitted treatments were not significantly different $(\mathrm{P}>0.05)$ from those in the complete treatment. The number of leaves in the complete treatment was similar to that of the nutrient omissions for $\mathrm{Mg}$, micronutrients, $\mathrm{N}, \mathrm{S}, \mathrm{Ca}, \mathrm{P}$ and $\mathrm{K}$. The greatest number of leaves per plant was observed in $\mathrm{K}$ omitted treatment although it was not significantly $(P>0.05)$ different from the complete treatment (Fig.5).

Effect of treatment on number of leaves per pot in Umbrisol. In Umbrisol, the number of leaves in the complete treatment was similar to that of the nutrient omissions for $\mathrm{Mg}, \mathrm{Ca}$, micronutrients, $\mathrm{S}$ and $\mathrm{K}$. The greatest number of leaves per plant was observed in $\mathrm{Mg}$ omitted treatment, although it was not significantly $(\mathrm{P}$

Number of leaves

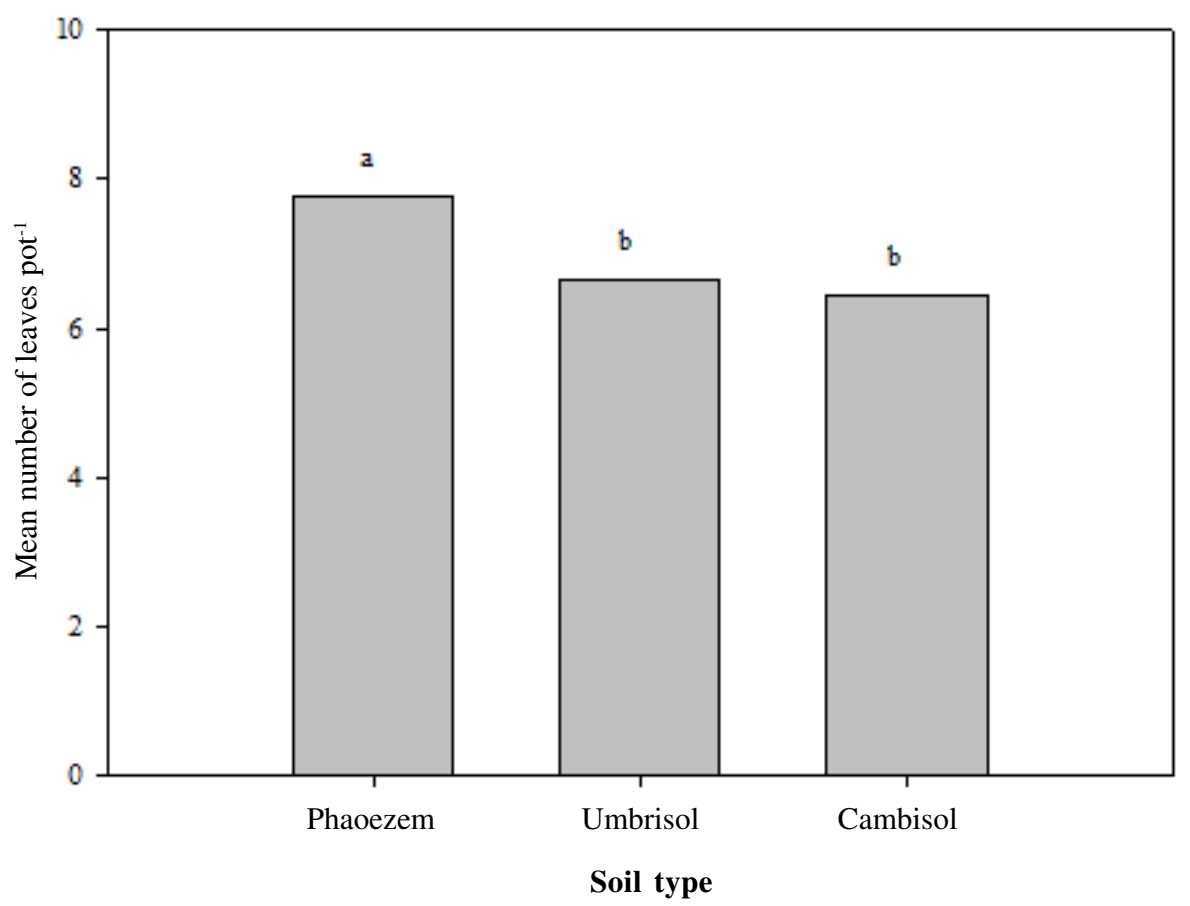

Figure 4. Number of bean leaves per pot growing on different soil types in Masaka District in Uganda. 
Cambisol

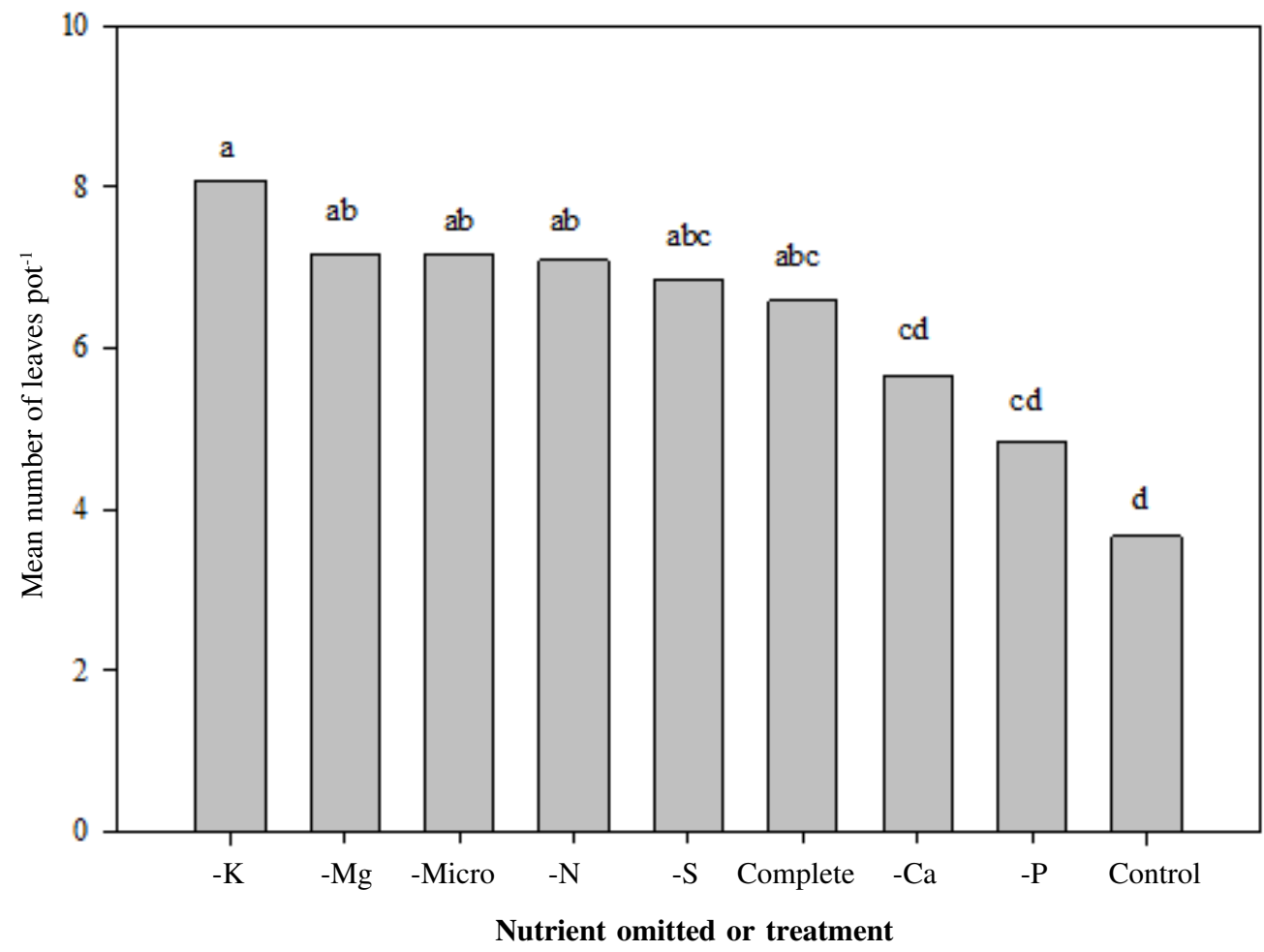

Figure 5. Number of leaves per bean plant grown on a Cambisol in a nutrient omission study.

$>0.05)$ different from the complete treatment (Fig. 6). Plants grown in the complete nutrient treatment had significantly $(\mathrm{P}<0.05)$ more leaves than their counterparts grown in phosphorus and nitrogen omitted treatments. Plants grown in the control had the fewest number of leaves $(\mathrm{P}<0.05)$, fewer than the complete treatment, but not significantly $(\mathrm{P}>$ 0.05 ) different from phosphorus and nitrogen omitted treatment (Fig. 6). Incidentally, the number of leaves in phosphorus and nitrogen omitted treatments also were not significantly different $(\mathrm{P}>0.05)$.

\section{DISCUSSION}

Effect of soil type on above ground dry matter production. The accumulation of significantly higher $(\mathrm{P}<0.05)$ above ground dry matter in Phaeozem than that from Cambisol and Umbrisol (Fig. 1) could be attributed to differences in nutrient levels. It seems likely that with the low $\mathrm{pH}$ values of the Umbrisol and the Cambisol (Table 3) and the high levels of extractable Al, that soil acidity was the main reason for growth differences among the three soils. Phaeozem had greater available P, total $\mathrm{N}$ and OM (Table 3) compared to other soils.

In summary, bean growth on the Umbrisol was better than that of the Cambisol, but not as great as that on the Phaeozem soil, documenting that Liddugavu is the better soil for bean production. The results of this nutrient omission study suggest some potential options to improve yields of bean on the Cambisol, and Umbrisol soils.

Effect of nutrient omission on dry matter production in Phaoezem. In Phaoezem soil, bean plants grew the best among the three representative soils, but less growth was 
Umbrisol

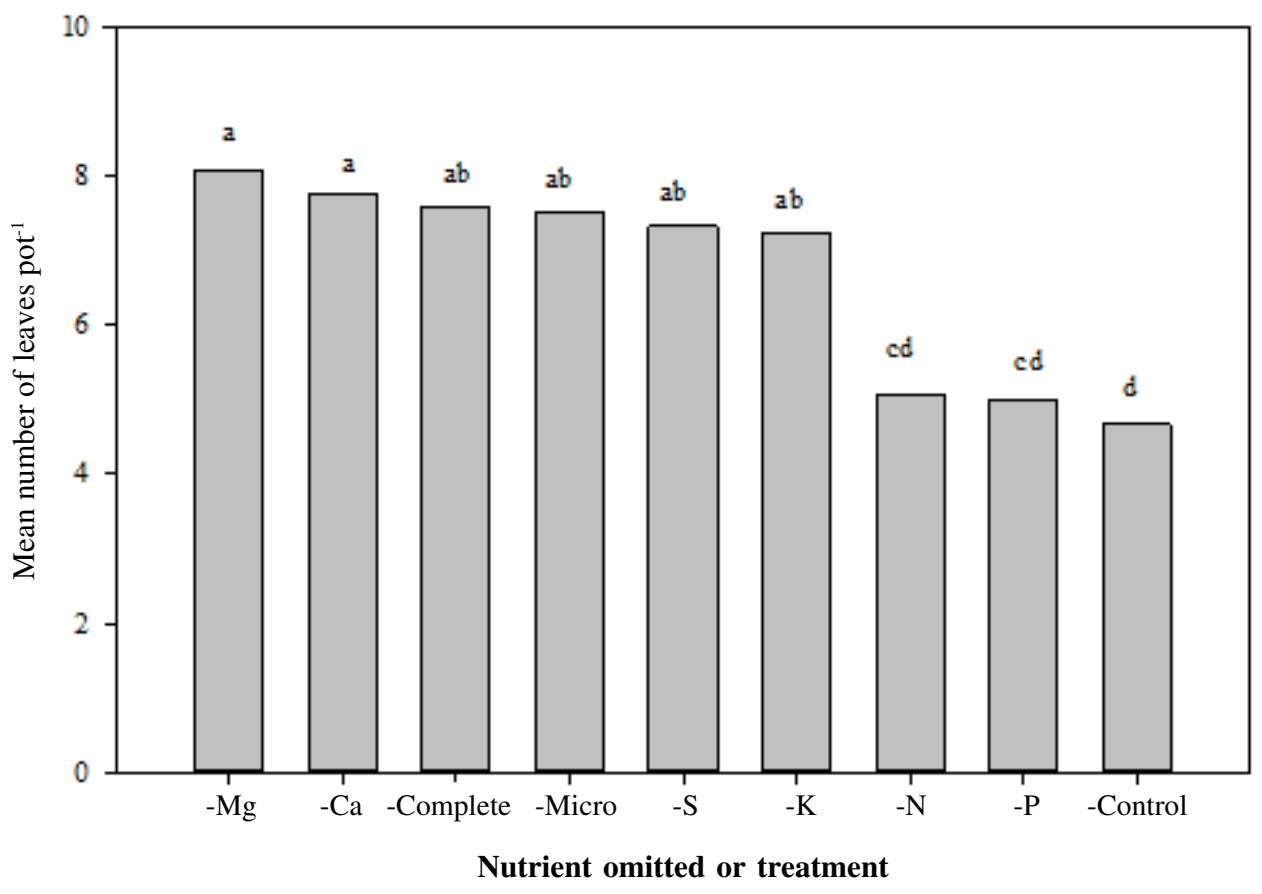

Figure 6. Number of leaves per bean plant grown in an Umbrisol in a nutrient omission study.

observed in the control with no nutrients (Fig. 2). The complete treatment yielded slightly higher above ground dry matter than the $\mathrm{N}$ omitted treatment. These results provide scientific data supporting the farmer experience in growing beans on this soil type, where they mentioned that it is the best soil for growing beans.

Effect of nutrient omission on dry matter production in Umbrisol. In distinction with the highly productive Phaoezem soil and the extremely impoverished Cambisol soil; the Umbrisol, yielded intermediate in total bean dry matter production (Fig. 3). The complete treatment had greater above ground dry matter than the $\mathrm{N}, \mathrm{P}$ and $\mathrm{K}$ omitted treatments and the control without any nutrient (Fig. 3), suggesting that these nutrients in particular, were needed for best bean growth. The complete treatment was not significantly $(\mathrm{P}>$ $0.05)$ different from all other omission treatments. This can be attributed to the low levels of $\mathrm{N}, \mathrm{P}$ and $\mathrm{K}$ that were below the critical values in Umbrisol (Table 3).

A lingering question is what would the yield have been, had the soil $\mathrm{pH}$ been increased with the addition of limestone and the levels of toxic Al reduced (Table 3). We therefore, recommend a follow up study.

The lack of difference among the nutrients other than N, P, K and the control (Fig. 3) might be due to the Law of the Minimum.

The least aboveground dry matter production in the control and phosphorus omitted treatments (Fig. 3) could be attributed to P deficiency. According to Fageria (2006), if $\mathrm{P}$ is deficient, plants dependent on $\mathrm{N}_{2}$ fixation are limited in their production because $\mathrm{P}$ is an important element required for $\mathrm{N}_{2}$ fixation. Maximum benefits from $\mathrm{N}_{2}$ fixation depend on soil $\mathrm{P}$ availability (Kennedy and Cocking, 1997; Graham et al., 2003).

Clearly, nitrogen, phosphorus and potassium were limiting nutrients for bean dry matter production in Umbrisol soil. 
Effect of nutrient omission on number of leaves per plant. In Phaeozem, all nutrient omitted treatments and the control treatment were not significantly different from the complete treatment (Fig. 4). This is consistent with what farmers mentioned that this soil type was the best for common bean production. The better performance in this soil could be explained by the inherent fertility of the soil whereby all other nutrients were above the critical value apart from total $\mathrm{N}$ and organic matter (Table 3).

Effect of nutrient omission on number of leaves per plant. In Cambisol, beans grown in the complete treatment had significantly ( $P$ $<0.05)$ more leaves than did the control without nutrients added (Fig. 5). These results are most likely consistent with the low soil $\mathrm{pH}$ and its poor nutrient status (Table 3). This extremely fewer number of bean leaves on this soil without any added nutrient is a sharp reminder of how acid and impoverished this soil is, an observation heard frequently from farmers during the community interviews.

In Umbrisol, bean plants grown in the complete treatment had significantly $(\mathrm{P}<0.05)$ more leaves than beans grown in the $\mathrm{N}$ and $\mathrm{P}$ omitted treatments (Fig. 6), indicating that limited $\mathrm{P}$ and $\mathrm{N}$ availability were limiting leaf production in the tested soil.

The observation of significantly $(\mathrm{P}<0.05)$ fewer number of leaves in the control, $\mathrm{P}$ and $\mathrm{N}$ omitted treatments (Fig. 6) could be explained by the low levels of these nutrients in the tested soil. The soil was poor in total $\mathrm{N}$ and available P right from the begining (Table $3)$. As a result, growth decreased when $\mathrm{N}$ and $\mathrm{P}$ were omitted. Results from this study are in conformity with the findings of Hossain and Hamid (2007) in groundnut where plants grown under no application of $\mathrm{N}$ and $\mathrm{P}$ fertiliser on weathered soils were stunted with fewer and smaller leaves, and poor yield.

\section{CONCLUSION}

Phosphorus was the most limiting nutrient for bean production in Umbrisol and this was followed by $\mathrm{N}$ and $\mathrm{K}$. In Cambisol, common bean production was most limited by soil acidity. The performance varied with soil types with bean grown on the Phaeozem registering greater leaf number and growth followed by Umbrisol, confirming both local scientist and farmer knowledge that this soil has greater potential than the other two soils.

\section{ACKNOWLEDGEMENT}

We gratefully acknowledge funding for this study from the USAID Feed the Future Legume Innovation Laboratory for Collaborative Research on Grain Legumes project on 'Farmer Decision Making Strategies for Improved Soil Fertility Management in Maize-Bean Production Systems'.

\section{REFERENCES}

Asher, C., Grundon, N. and Menzies, N. 2002. How to unravel and solve soil fertility problems. Australia, ACIAR Monograph No. 83. 139pp.

Beebe, S., Rao, I., Mukankusi, C. and Buruchara, R. 2010. Improving resource use efficiency and reducing risk of common bean production in Africa, Latin America, and the Caribbean. https:// core.ac.uk/download/pdf/132666015.pdf Accessed on $12^{\text {th }}$ April 2013.

Berger, K.C. and Truog, E. 1939. Boron determination in soils and plants. Industrial \& Engineering Chemistry Analytical Edition 11:540-545.

Bouyoucos, G.J. 1936. Directions for Making Mechanical Analysis of Soils by the Hydrometer Method. Soil Science 4:225228 
Bremner, J.H. 1965. Total nitrogen. In: Black, C.A., Evans, D.D., White, J.L., Ensminger, L.E., Clark, F.E. and Dinauer, R.C. (Eds.). Methods of soil analysis. Part 2. ASA, Madison, Wisc., USA. pp. 11491178.

Fageria, N.K. 2006. Nutrient interactions in crop plants. Journal of Plant Nutrition 24(8):1269-1290. DOI.10.1081/PLN100106981 .

Foli, S.K. 2012. Qualitative and quantitative diagnosis of macro and micronutrient deficiencies in soils across three agroecological environments of northern Nigeria using the double-pot technique. MSc internship report, Wageningen University, Wageningen, The Netherlands. July 2012. pp. 11-23.

Hewitt, E.J. 1952. Sand and water culture methods used in the study of plant nutrition. Technical Communication No. 22 of the commonwealth bureau of horticulture and plantation crops, East Malling, Maidstone, Kent. First Edn. pp.241.

Hoagland, D.R. and Arnon, D.I. 1950. The water-culture method for growing plants without soil. California Agricultural Experiment Station Circular 347:1-32.

Hossain, M.A. and Hamid, A. 2007. Influence of $\mathrm{N}$ and $\mathrm{P}$ fertilizer application on root growth, leaf photosynthesis and yield performance of groundnut. Bangladesh Journal of Agricultural Research 32(3):369-374.

Johnston, M. and Askin, D. 2005. Container grown experiments. http://ard.nari.org.pg/ uploads/library/johnston/2005/ 65 Johnston2005.doc. Accessed on $20 \mathrm{Feb}$ 2014. Korea. pp. 14-29

Kabuga, E., Miiro, R., Tenywa, M.M. and Semalulu, O. 2015. Foliar feeding decision in Masaka District. Farmer decisionmaking strategies for improved soil fertility management in maize-bean production systems. Focus group and key informant interviews with bean farmers in Masaka and Rakai District, Uganda. Unpubl. Report.
Project S02.1-Annual Report for 2013-14. October 2015. 14pp.

Kipe-Nolt, J. and Giller, K. 1993. A field evaluation using $15 \mathrm{~N}$ isotope dilution method of lines of Phaseolus vulgaris L. bred for increased nitrogen fixation. Plant Soil 134:178.

Mauyo, L.W., Okalebo, J.R., Kirkby, R.A., Buruchara, R., Ugen, M., Mengist, C.T., Anjichi, V.E. and Musebe, R.O. 2007. Technical efficiency and regional market integration of cross-border bean marketing in western Kenya and eastern Uganda. African Journal of Business Management pp. 077-084.

Mehlich, A. 1984. Mehlich 3 soil test extractant: A modification of the Mehlich 2 extractant. Communications in Soil Science and Plant Analysis 15(12):14091416.

Okalebo, J.R., Gathua, K.W. and Woomer, P.L. 2002. Laboratory methods of soil and plant analysis: A Working Manual; $2^{\text {nd }}$ Edition. Sacred African Publishers, Nairobi, Kenya. 128.

Rhoads, J.D. 1982. Soil testing, In: Page, A.1., Miller, R.M. and Keeney, D.R. (Eds.). Methods of Soil Analysis-Part 2. $2^{\text {nd }}$ edition. American Society of Agronomy 1621.

Sanginga, N. and Woomer, P.L. 2009. Integrated soil fertility management in Africa: Principles, Practices and Development Process. Tropical Soil Biology and Fertility Institute of the International Centre for Tropical Agriculture. Nairobi, Kenya. 263pp.

Sibiko, K.W., Mwangi, J.K., Gido, E.O., Ingasia, O.A. and Mutai, B.K. 2013. Allocative efficiency of smallholder common bean producers in Uganda: A stochastic frontier and Tobit model approach. International Journal of Development and Sustainability Online ISSN: 2168-8662 - www.isdsnet.com/ijds 2 (2): 640-652. 
Tenywa, M.M., Semalulu, O., Luswata, C.K., Kyomuhendo, P., Namakula, J., Abbott, E., Yost, R., and Kabango, F. 2014. Farmer decision-making strategies for improved soil fertility management in maize-bean production systems. Focus group interviews with bean farmers in Masaka and Rakai Districts, Uganda. (Unpubl. Report). Project S02.1-Annual Report for 2013-14. October 2014.

Timkhum, P., Maneepong, S., Issarakrisila, M., and Sangsing, K. 2013. Nutrient assessment with omission pot trials for management of rubber growing soil. Journal of Agricultural Sciences 5:10-19. doi:10.5539/jas.v5n10p.

Tukey, J.W. 1949. Comparing Individual Means in the Analysis of Variance. Biometrics 5(2):99-114.

UBOS. 2006. Uganda Bureau of Statistics (UBOS). 2006. National Household survey, Agricultural Module, Kampala, Uganda. 41pp. 